\title{
Effect of Iron Nanoparticles Synthesized by a Sol-Gel Process on Rhodococcus erythropolis T902.1 for Biphenyl Degradation
}

\author{
Wissal Wannoussa ${ }^{* \#}$, Thibaut Masy ${ }^{1 *}$, Stéphanie D. Lambert², Benoît Heinrichs², \\ Ludivine Tasseroul ${ }^{2}$, Alaaeddin Al-Ahmad ${ }^{1}$, Frédéric Weekers ${ }^{3}$, Philippe Thonart ${ }^{1}$, \\ Serge Hiligsmann 1 \\ ${ }^{1}$ Walloon Center of Industrial Biology, Department of Chemistry and Bio-industries, University of Liège, \\ Gembloux, Belgium \\ ${ }^{2}$ Laboratory of Nanomaterials, Catalysis and Electrochemistry, University of Liège, Liège, Belgium \\ ${ }^{3}$ Artechno S.A., Gembloux-Les Isnes, Belgium \\ Email: "wissalwanoussa@hotmail.com, ”s.hiligsmann@ulg.ac.be
}

Received 6 February 2015; accepted 24 February 2015; published 27 February 2015

Copyright (C) 2015 by authors and Scientific Research Publishing Inc.

This work is licensed under the Creative Commons Attribution International License (CC BY).

http://creativecommons.org/licenses/by/4.0/

cc) (i) Open Access

\begin{abstract}
Nanoparticles $\left(N P_{S}\right)$ are considered as a new generation of compounds to improve environmental remediation and biological processes. The aim of this study is to investigate the effect of iron $\mathrm{NP}_{\mathrm{S}}$ encapsulated in porous silica $\left(\mathrm{SiO}_{2}\right)$ on the biphenyl biodegradation by Rhodococcus erythropolis T902.1 (RT902.1). The iron NPs (major iron oxide $\mathrm{Fe}_{\mathrm{x}} \mathrm{O}_{\mathrm{y}}$ form) were dispersed in the porosity of a $\mathrm{SiO}_{2}$ support synthesized by sol-gel process. These $\mathrm{Fe} / \mathrm{SiO}_{2} \mathrm{NP}_{\mathrm{S}}$ offer a stimulating effect on the biodegradation rate of biphenyl, an organic pollutant that is very stable and water-insoluble. This positive impact of $\mathrm{NP}_{S}$ on the microbial biodegradation was found to be dependent on the $\mathrm{NP}_{S}$ concentration ranging from $10^{-6} \mathrm{M}$ to $10^{-4} \mathrm{M}$. After 18 days of incubation the cultures containing $\mathrm{NP}_{S}$ at a concentration of $10^{-4} \mathrm{M}$ of iron improved RT902.1 growth and degraded $35 \%$ more biphenyl than those without NPs (positive control) or with the sole $\mathrm{SiO}_{2}$ particles. Though the microorganism could not interact directly with the insoluble iron $\mathrm{NP}_{\mathrm{s}}$, the results show that about $10 \%$ and $35 \%$ of the initial $10^{-4} \mathrm{M}$ iron $\mathrm{NP}_{\mathrm{S}}$ encapsulated in the $\mathrm{SiO}_{2}$ matrix would be incorporated inside or adsorbed on the cell surface respectively and $35 \%$ would be released in the supernatant. These results suggest that RT902.1 would produce siderophore-like molecules to attract iron from the porous silica matrix.
\end{abstract}

\footnotetext{
${ }^{*}$ Contributed equally.

"Corresponding author.
}

How to cite this paper: Wannoussa, W., et al. (2015) Effect of Iron Nanoparticles Synthesized by a Sol-Gel Process on Rhodococcus erythropolis T902.1 for Biphenyl Degradation. Journal of Water Resource and Protection, 7, 264-277. 


\section{Keywords}

\section{Biodegradation, Biphenyl, Rhodococcus erythropolis, Encapsulated Nanoparticles, Sol-Gel, Iron}

\section{Introduction}

Bioremediation of polluted soils is considered as a more effective and sustainable method to remove pollutants than physico-chemical technologies. It is also preferred to direct disposal of toxic and hazardous wastes [1] [2]. However, the bioremediation kinetics are very limited. Indeed, long time periods of a few months are needed for microbial degradation of highly complex or hydrophobic substances such as polyaromatic and polycyclic hydrocarbons.

Some studies showed that using certain metal ions at low concentrations accelerates the biodegradation rate [3]-[7]. Similarly, Chun-Wei and Barbara [8] demonstrated that the addition of cadmium, copper and chrome at low concentration of $0.01 \mathrm{ppm}$ (i.e. about $10^{-7} \mathrm{M}$ ) enabled to achieve a 2-fold higher biodegradation rate of phenol, benzoate or 2-chlorophenol. By contrast, when comparing to the kinetics achieved at $2.5 \times 10^{-5} \mathrm{M}$ of metal, Kotresha and Vidyasagar [9] reported a 2-fold decrease of phenol biodegradation rate by P. aeruginosa MTCC 4996 in presence of $2 \times 10^{-4} \mathrm{M}$ of cobalt or nickel and up to $1.5 \times 10^{-3} \mathrm{M}$ of copper, cadmium or zinc. Furthermore these elements are heavy metals not suitable for environmental applications.

On the contrary, metallic iron may be accepted for environmental applications since it is less expensive and has a lower toxicity compared with the other metals [3] [9]-[11]. Bunescu et al. [3] reported that the presence of iron up to $10^{-3} \mathrm{M}$ did not inhibit the biodegradation of 2-aminobenzothiazol by Rhodococcus rhodochrous. In contrast, Lin et al. [10] reported that the presence of copper at $1 \mathrm{mg} / \mathrm{L}$ and $10 \mathrm{mg} / \mathrm{L}$ (i.e. $7 \times 10^{-6} \mathrm{M}-7 \times 10^{-5} \mathrm{M}$ ) significantly reduced the degradation rate of methyl tert-butyl ether by $P$. aeruginosa.

Iron addition in the culture medium was shown to be effective for reductive degradation of a variety of toxic substances such as aromatic compounds [12] [13]. Santos et al. [12] showed that the presence of different forms of soluble iron at the concentrations of $10^{-4} \mathrm{M}\left(\mathrm{FeCl}_{3}, \mathrm{Fe}\left(\mathrm{NO}_{3}\right)_{3}, \mathrm{Fe}_{2} \mathrm{O}_{3}, \mathrm{FeSO}_{4}\right)$ had a positive impact on cell growth and biodegradation of anthracene by Pseudomonas sp. with up to $25 \%$ higher biodegradation yield than in the control test with iron nitrate, the most soluble iron form. By contrast, concentrations higher than $2 \times 10^{-4} \mathrm{M}$ of this salt showed to inhibit the microorganisms. Chorao [13] emphasized that the use of a Fe (III)-nitrilotriacetic acid complex (FeNTA) up to $10^{-3} \mathrm{M}$ stimulated the biodegradation of 2-aminobenzothiazol by Rhodococcus rhodochrous.

These recent studies used different forms of iron: iron salts and iron complexes for the optimization of pollutant biodegradation. By comparison, the iron $\mathrm{NP}_{\mathrm{S}}$ are preferred as they have a large surface area and high reactivity [14]. Moreover, when compared to many other metallic $\mathrm{NP}_{\mathrm{S}}$, the iron $\mathrm{NP}_{\mathrm{S}}$ are stable, less expensive and less toxic for use with the microorganisms. They are therefore suitable for large scale industrial applications such as bioreactors for water treatment [15].

Previous studies demonstrated that using iron $\mathrm{NP}_{\mathrm{S}}$ (individual or joint with other metal) accelerates the biodegradation of pollutants [14] [16]. Murugesan et al. [16] reported that the presence of palladium-iron bimetallic $\mathrm{NP}_{\mathrm{S}}$ (nFe-Pd) up to $0.1 \mathrm{~g} / \mathrm{L}$ (estimated at $2 \times 10^{-3} \mathrm{M}$ Fe and $2 \times 10^{-6} \mathrm{M} \mathrm{Pd}$ ) in minimal salt medium is effective on the complete dechlorination of triclosan (2, 4, 40-trichloro 20-hydroxydiphenyl ether; up to $27 \mathrm{ppm}$ initial concentration) and biodegradation of the intermediates metabolites by a strain of Sphingomonas. Zhang [14] showed that using iron $\mathrm{NP}_{\mathrm{S}}$ is very effective for the transformation of a wide variety of common environmental contaminants such as chlorinated organic solvents.

Currently, the nanomaterials open up a window for a range of applications in numerous fields as well as usual products and processes [17]. For example, the $\mathrm{NP}_{\mathrm{S}}$ of titanium dioxide $\left(\mathrm{TiO}_{2}\right)$ are used for self-cleaning surfaces, for treatment of polluted water and in sun creams [18]. $\mathrm{SiO}_{2} \mathrm{NP}_{\mathrm{S}}$ are used as an anti-clumping-agent in common salt [18]. In the biological field, the $\mathrm{NP}_{\mathrm{S}}$ have a wide range of applications. On the one hand, the nanomaterials are used as antibacterial agents (i.e. $\mathrm{NP}_{\mathrm{S}}$ of silver) [19] [20]. On the other hand, some microorganisms may take advantages of nanoparticles to improve their potential in biological processes [21]. These applications have attracted much attention of researchers to develop new methods for the synthesis of the nanomaterials with specific properties such as thermal stability, high porosity and large surface area [22]-[25]. 
The objective of this work was to improve biphenyl biodegradation by RT902.1 using iron $\mathrm{NP}_{\mathrm{S}}$ encapsulated in porous silica $\mathrm{SiO}_{2}$ synthesized by sol-gel methods. Indeed, several authors used the sol-gel method to obtain monometallic catalyst particles finely dispersed on a mineral support [26]. The process is based on the simultaneous hydrolysis and condensation of two alkoxysilanes: an $\mathrm{SiO}_{2}$ network-forming reagent such as tetraethoxysilane (TEOS or Si $\left.\left(\mathrm{OC}_{2} \mathrm{H}_{5}\right)_{4}\right)$ and an alkoxysilane-functionalized ligand of the type (RO) ${ }_{3} \mathrm{Si}-\mathrm{X}-\mathrm{A}$, in which a functional organic group $\mathrm{A}$, able to form a chelate with a cation of a metal such as iron, palladium or copper is linked to the hydrolyzable silyl group (RO) ${ }_{3} \mathrm{Si}$ - via an inert and hydrolytically stable spacer $\mathrm{X}$ [22]-[24]. The iron $\mathrm{NP}_{\mathrm{S}}$ are encapsulated in the form of metal oxide $\left(\mathrm{Fe}_{\mathrm{x}} \mathrm{O}_{\mathrm{y}}\right)$ in an inert matrix of silica. There is no chemical bond between $\mathrm{SiO}_{2}$ and $\left(\mathrm{Fe}_{\mathrm{x}} \mathrm{O}_{\mathrm{y}}\right)$. This is a physical blocking of metal oxides $\mathrm{NP}_{\mathrm{S}}$ of 2 to 3 nm size in microporous $\mathrm{SiO}_{2}$ crystallite (10 to $20 \mathrm{~nm}$ diameter) whose internal porosity is less than $1 \mathrm{~nm}$.

The mechanism involved in the improvement of biphenyl biodegradation by RT902.1 and mediated by NP $_{S}$ was investigated via the mass balance of iron liberated from the capsule of $\mathrm{SiO}_{2}$ and the enzymes involved in the two stages of biphenyl biodegradation (hydroxylation and cleavage of aromatic ring).

\section{Materials and Methods}

\subsection{Preparation and Characterization of Iron $\mathrm{NP}_{\mathrm{S}}$ and $\mathrm{SiO}_{2}$}

The $\mathrm{Fe} / \mathrm{SiO}_{2} \mathrm{NP}_{\mathrm{S}}$ were prepared by the sol-gel method, as described by Heinrichs et al. [27]. This method consists of dissolving the iron (III) acetyl acetonate $\left(\mathrm{Fe}\left[\mathrm{CH}_{3} \mathrm{COCHCOCH}_{3}\right]_{3}\right)$ in the initial homogenous solution of silica gel precursor tetraethoxysilane $\left(\mathrm{Si}\left(\mathrm{OC}_{2} \mathrm{H}_{5}\right)_{4}\right.$ or TEOS). This complex dried at $80^{\circ} \mathrm{C}$ after the gelation $(\mathrm{Fe} /$ $\mathrm{SiO}_{2}$ dried). It is further calcined at high temperature $\left(450^{\circ} \mathrm{C}\right.$ to $\left.550^{\circ} \mathrm{C}\right)$ to remove organic waste material and achieve the $\mathrm{SiO}_{2}$ porous matrix encapsulating the iron oxide crystallites of $\mathrm{Fe}_{\mathrm{x}} \mathrm{O}_{\mathrm{y}}\left(\mathrm{Fe} / \mathrm{SiO}_{2}\right.$ calcined). Moreover, the porous silica matrix without $\mathrm{NP}_{\mathrm{S}}$, denoted $\mathrm{SiO}_{2}$, was also synthesized by the sol-gel process to study the effect of the sole matrix of $\mathrm{SiO}_{2}$ on biphenyl biodegradation [24]. The samples were characterized (textural analysis, electron microscopy, X-ray diffraction) by using the methods described by Lambert et al. [24] and Heinrichs et al. [27]. They showed that the catalyst $\mathrm{Fe} / \mathrm{SiO}_{2}$ calcined contained $1.53 \%(\mathrm{w} / \mathrm{w})$ of active metal iron encapsulated in porous silica [27]. A $10^{-2} \mathrm{M} \mathrm{Fe} / \mathrm{SiO}_{2}$ suspension was prepared using $1.86 \mathrm{~g}$ of Fe/SiO ${ }_{2}$ catalyst (agglomerates of microporous silica particles encapsulating iron $\mathrm{NP}_{\mathrm{S}}$ produced by sol-gel process and finely pounded at micrometersize for accurate weighing) in $50 \mathrm{~mL}$ ultrapure water (Milli-Q water, $18.2 \mathrm{M} \Omega \mathrm{cm}$ ). According to the experimental conditions, a defined volume of the homogenized $10^{-2} \mathrm{M} \mathrm{Fe} / \mathrm{SiO}_{2}$ suspension was transferred rapidly, due to fast settlement, in the culture medium prior to sterilization in order to reach a final iron concentration ranging from $10^{-4}$ to $10^{-6} \mathrm{M}$.

\subsection{Cultures}

Precultures were prepared in $250 \mathrm{~mL}$ baffled flasks containing $50 \mathrm{~mL}$ of M284 minimal medium [28], complemented by $5 \mathrm{~g} / \mathrm{L}$ of glucose. The medium was sterilized for 20 minutes at $121^{\circ} \mathrm{C}$ and cooled down to room temperature before inoculation at an initial cell density of about $10^{9} \mathrm{cell} / \mathrm{mL}$ by transfer of colonies of RT902.1 developed on M284 + agar medium. The microbial suspension was incubated for 3 days at $30^{\circ} \mathrm{C}$ and $150 \mathrm{rpm}$ orbital agitation. The glucose was totally consumed after 3 days of incubation (assayed by the Kit RTU glucose BioMerieux, F). For the biphenyl biodegradation experiments, the culture medium was prepared similarly in 100 $\mathrm{mL}$ flasks (in triplicates) with $20 \mathrm{~mL}$ M284 minimal medium supplemented with calcined or dried iron $\mathrm{NP}_{\mathrm{S}}$ at concentrations ranging from 0 (positive control) to $10^{-4} \mathrm{M}$ of metal element. After sterilization, $1 \mathrm{~mL}$ of a 10 $\mathrm{g} / \mathrm{L}$ biphenyl solution in $n$-hexane was added on the culture medium to achieve a biphenyl initial concentration of 500 ppm as source of carbon and energy. The evaporation of $n$-hexane was allowed overnight under a ventilated hood leaving biphenyl crystals suspended in the M284 minimal medium. A relatively homogenous suspension of biphenyl crystals in aqueous phase was achieved by vigorous mixing for 2 minutes using a mixer (POLYTRON $^{\circledR}$ PT 1200 E, KINEMATICA AG, CH) sterilized by immersion in three successive solutions: SDS $5 \%$, sodium hypochlorite $4 \%$ and norvanol $9 \%$. The resulting suspension was inoculated with $3 \mathrm{~mL}$ of preculture and incubated at $30^{\circ} \mathrm{C}(150 \mathrm{rpm}$ orbital agitation). Test controls were also prepared in the same conditions but without added $\mathrm{NP}_{\mathrm{S}}$ nor $\mathrm{SiO}_{2}$ (positive control), with the sole $\mathrm{SiO}_{2}$ matrix (positive control $+\mathrm{SiO}_{2}$ ) or without inoculum (negative control with or without $\mathrm{Fe} / \mathrm{SiO}_{2} \mathrm{NP}_{\mathrm{S}}$ ). The negative controls were carried out in triplicates to examine the abiotic removal/evaporation of biphenyl. The optical density was measured at $600 \mathrm{~nm}$ (Ultrospec 
III, Pharmacia LKB) at different time points of incubation (after 3, 8 and 18 days). The interference of $\mathrm{NP}_{\mathrm{S}}$ on absorbance was corrected with the control samples that contained only $\mathrm{NP}_{\mathrm{S}}$ to confirm the bacterial growth.

\subsection{Biphenyl and Major Metabolites Analysis}

Biphenyl residual concentration in the culture medium was measured by HPLC at different time points of incubation (after 3, 8 and 18 days) after liquid-liquid extraction in organic solvent. Glass tubes of a total volume of $10 \mathrm{~mL}$ (culture tube $16 \times 100$ SVL SCRE, PyrexR, UK) with Teflon seal and containing $2 \mathrm{~mL}$ sample and $4 \mathrm{~mL}$ $n$-hexane were mixed for $24 \mathrm{~h}$ at $30^{\circ} \mathrm{C}$. After centrifugation at $7000 \mathrm{rpm}$ (SAL-1500 rotor in SorvallR RC5B+ centrifuge) for 15 min the organic phase was transferred in glass tubes for overnight evaporation of solvent under a constant ventilated hood. Crystals of biphenyl were resuspended in $10 \mathrm{~mL}$ methanol before analysis by HPLC. The major metabolites from biphenyl biodegradation i.e. catechol and benzoic acid were analyzed in the aqueous phase recovered after liquid-liquid extraction. It was centrifuged at 13,000 rpm for 2 min and the supernatant was filtered through a $0.2 \mu \mathrm{m}$ cellulose acetate filter before HPLC analysis. HPLC analyses were performed using an Agilent 1100 Series equipment and a C18 column (LiChroCART ${ }^{\circledR}$ 250-4.6 HPLC-cartridge Purospher ${ }^{\circledR}$ STAR RP-18 endcapped $5 \mu \mathrm{m}$, Merck, D) maintained at $30^{\circ} \mathrm{C}$. The mobile phase contained acetonitrile and Milli-Q water in the ratio 70/30 or 35/65 in order to determine the biphenyl concentration or the metabolites respectively. Its $\mathrm{pH}$ was adjusted to 2.75 with $1.5 \mathrm{M}$ phosphoric acid. The flow rate was $0.8 \mathrm{~mL} / \mathrm{min}$ and $10 \mu \mathrm{L}$ of the sample were injected. Biphenyl, benzoic acid and catechol were detected at $254 \mathrm{~nm}$ and their concentration in samples was calculated from a standard graph determined using pure compounds.

\subsection{Recycling of Calcined Iron NPS}

After 18 days of incubation, the culture was centrifuged at $7000 \mathrm{rpm}$ for $15 \mathrm{~min}$. The pellet was calcined for 4 hours in porcelain crucible directly on the flame in order to completely oxidize the organic compounds. After calcination, the inorganic matrix was added for a first cycle in $100 \mathrm{~mL}$ flasks, with $20 \mathrm{~mL}$ of M284 minimal medium and $3 \mathrm{~mL}$ of fresh inoculum. The supernatant volume of the culture (about $14 \mathrm{~mL}$ after 3 samples collection of $2 \mathrm{~mL}$ ) was transferred in another $100 \mathrm{~mL}$ flask supplemented to $20 \mathrm{~mL}$ with M284 minimal medium before inoculation with $3 \mathrm{~mL}$ of fresh inoculum. A second and a third cycles were carried out using the same procedure applied to the flasks containing the $\mathrm{NP}_{\mathrm{S}}$ and also for the control culture (without $\mathrm{NP}_{\mathrm{S}}$ ).

\subsection{Iron Titration}

The total iron concentration was determined using the method slightly modified from Bunescu [29]. The total iron concentration was determined after the reduction of $\mathrm{Fe}^{3+}$ with a solution of ascorbic acid (3\%) and reaction with orthophenanthroline forming a strong-colored complex with $\mathrm{Fe}^{2+}$. In a $10 \mathrm{~mL}$ flask, $300 \mu \mathrm{L}$ of sample were mixed with $4200 \mu \mathrm{L}$ of ascorbic acid ( $3 \% \mathrm{w} / \mathrm{v}$ in ultrapure water) and stirred. After, 2 min wait and addition of $500 \mu \mathrm{L}$ of a $1 \%$ orthophenanthroline solution (w/v in ethanol for analysis), the optical density was measured at $510 \mathrm{~nm}$. This procedure was used to determine the iron concentration in the different compartments of the RT902.1 biomass (extracellular, intracellular, and at the cell surface) at the end of the experiment (after 18 days of incubation) with calcined $10^{-4} \mathrm{M} \mathrm{Fe} / \mathrm{SiO}_{2}$ and $500 \mathrm{ppm}$ biphenyl. According to Bezkorovainy et al. [30] $4 \mathrm{~mL}$ of the culture medium (in triplicates) was sampled after rapid settlement of $\mathrm{Fe} / \mathrm{SiO}_{2}$ catalyst and separated into two fractions. The first $2 \mathrm{~mL}$ fraction (way A was centrifuged at 13,000 rpm for $20 \mathrm{~min}$ before measurement of the soluble iron in the supernatant $\left(\mathrm{A}_{0}\right)$. The pellet was washed with $2 \mathrm{~mL}$ of ultrapure water (Milli-Q water, $18.2 \mathrm{M} \Omega \mathrm{cm}$ ). After centrifugation, the iron concentration in the supernatant (A1) was determined. This step with ultrapure water was repeated three times more. The sum $\left(A_{1}+A_{2}+A_{3}+A_{4}\right)$ gave the concentration of the iron absorbed at the surface of the cells. The pellet was then resuspended with $2 \mathrm{~mL}$ of ultrapure water, and the cells were disrupted by sonication at a frequency of $10 \mathrm{kHz}$ for $3 \mathrm{~min}$. After centrifugation at 13,000 rpm for 20 $\mathrm{min}$, iron concentration was measured in the supernatant $A_{5}$ and in the pellet after resuspension in $2 \mathrm{~mL}$ of ultrapure water $A_{6}$. The sum $\left(A_{5}+A_{6}\right)$ corresponds to the intracellular iron concentration. All the steps described previously were carried out at $4^{\circ} \mathrm{C}$. The second $2 \mathrm{~mL}$ fraction (way B) was disrupted by sonication at a frequency of $10 \mathrm{kHz}$ for $3 \mathrm{~min}$ and centrifuged at 13,000 rpm for $20 \mathrm{~min}$. The total iron concentration $\left(\mathrm{B}_{1}+\mathrm{B}_{2}\right)$ was determined as the sum of the soluble iron concentration in the supernatant $\left(\mathrm{B}_{1}\right)$ and the iron adsorbed on the cell membrane determined after analysis of the pellet resuspended in $2 \mathrm{~mL}$ ultrapure water $\left(\mathrm{B}_{2}\right)$. The concentration 
of the total iron measured in both fractions A and B (i.e. $9.8 \times 10^{-5} \mathrm{M} \pm 0.01$ and $11 \times 10^{-5} \mathrm{M} \pm 0.01$ respectively) were similar to the theoretical value of $10^{-4} \mathrm{M}$ confirming the suitability and accuracy of the procedure. The procedure applied to the positive control $\left(1.9 \times 10^{-5} \mathrm{M}\right.$ theoretical iron concentration due to the presence $\mathrm{Fe}^{\mathrm{III}} \mathrm{NH}_{4}$ citrate added in the culture medium at a higher level than in the first experiment of Figure $\mathbf{1}$ for better reproducibility) lead to a total iron concentration measured in the first fraction A (i.e. $2 \times 10^{-5} \mathrm{M} \pm 0.01$ ) that was close to that of the second fraction B (i.e. $9 \times 10^{-6} \mathrm{M} \pm 0.01$ ).

\subsection{Enzyme Assays}

For the enzyme assays needing larger biomass material, the cultures were carried out in $500 \mathrm{~mL}$ flasks (in triplicates) with $100 \mathrm{~mL}$ of M284 minimal medium complemented by iron $\mathrm{NP}_{\mathrm{S}}$ at concentrations of 0 (positive control) or $10^{-4} \mathrm{M}$ of metal element. The cultures were sterilized for 20 minute at $121^{\circ} \mathrm{C}$. After sterilization, $5 \mathrm{~mL}$ of $10 \mathrm{~g} / \mathrm{L}$ biphenyl solution in $n$-hexane were added as the sole carbon and energy source. The other steps were as described above (Section "Cultures"). After 18 days of incubation, the cells were centrifuged at 13,000 rpm for 20 min and washed twice with a potassium phosphate buffer $0.05 \mathrm{M}\left(\mathrm{K}_{2} \mathrm{HPO}_{4}, \mathrm{KH}_{2} \mathrm{PO}_{4}, \mathrm{pH}\right.$ 7.5. The pellets were resuspended in a sufficient volume of the same buffer to obtain a cellular concentration of $0.05 \mathrm{~g}$ of wet cells per mL. The cell suspension was then sonicated at a frequency of $10 \mathrm{kHz}$ for $2 \mathrm{~min}$ and centrifugated at 13,000 rpm for $40 \mathrm{~min}$. The supernatant containing crude cell free extracts was used to determine the biphenyl dioxygenase activity and catechol1, 2 dioxygenase activity. During all these operations, the extracts were maintained at $4^{\circ} \mathrm{C}$.

The biphenyl dioxygenase activity was determined as the initial rate of indigo formation monitored spectrophotometrically at $610 \mathrm{~nm}$. The molar extinction coefficient for indigo at $610 \mathrm{~nm}$ was calculated at $15.900 \mathrm{~L}$ $\mathrm{mol}^{-1} \cdot \mathrm{cm}^{-1}$ [31]. For the determination of specific rates of indigo formation, a $100 \mu \mathrm{L}$ volume of concentrated cell free extracts was added in a $1.5 \mathrm{~mL}$ tube preincubated for $5 \mathrm{~min}$ at $30^{\circ} \mathrm{C}$ to $390 \mu \mathrm{L}$ of $0.05 \mathrm{M}$ phosphate buffer $\left(\mathrm{K}_{2} \mathrm{HPO}_{4}, \mathrm{KH}_{2} \mathrm{PO}_{4}, \mathrm{pH} 7.5\right)$ and $10 \mu \mathrm{L}$ of a $10 \mathrm{M}$ indole solution in $\mathrm{N}, \mathrm{N}$ dimethlyl-formamide. The amount of indigo formed in the samples was calculated from a standard graph determined using pure compound of indigo. One unit of enzyme activity was expressed in $\mathrm{mg}$ of indigo liberated/minute/mg protein. For the determination of catechol1,2dioxygenase specific activity, a $100 \mu \mathrm{L}$ volume of concentrated cell-free extracts was added to $900 \mu \mathrm{L}$ of $0.05 \mathrm{M}$ phosphate buffer $\left(\mathrm{K}_{2} \mathrm{HPO}_{4}, \mathrm{KH}_{2} \mathrm{PO}_{4}, \mathrm{pH} 7.5\right)$ and $20 \mu \mathrm{L}$ of $10 \mathrm{mM}$ catechol. The specific activity was monitored at $260 \mathrm{~nm}(\varepsilon=16.8 \mathrm{mM})$ [32]. The amount of cis, cis-muconic acid formed in the samples was calculated from a standard graph determined using pure compound of cis, cis-muconic acid. One unit of enzyme activity was defined as the amount of enzyme catalyzing the production of $1 \mu \mathrm{mol}$ cis, cismuconic acid per minute at $30^{\circ} \mathrm{C}$.

\subsection{Protein Concentration}

Protein concentration in culture samples was measured by the Bradford method using Bovine Serum Albumin as a standard [33].

\subsection{Statistical Analysis}

The SAS software (SAS Institute 2001) was used for all statistical analyses. The general linear model (GLM) was used to determine whether the effect of metallic $\mathrm{NP}_{\mathrm{S}}$ was significant on the biodegradation potential of RT902.1. Least square means and standard errors were calculated. A $p$-value of $<0.05$ was chosen as the threshold for significance of all statistical comparisons.

\section{Results and Discussion}

\subsection{Biodegradation of Biphenyl in the Presence of Iron $\mathrm{NP}_{\mathrm{S}} \mathrm{Fe} / \mathrm{SiO}_{2}$ Synthesized by Sol-Gel Process}

Three biodegradation experiments were carried out successively in $100 \mathrm{~mL}$ flasks containing $20 \mathrm{~mL}$ of M284 culture medium with $500 \mathrm{ppm}$ biphenyl and inoculated by $3 \mathrm{~mL}$ of preculture. First we investigated the effect of calcined iron $\mathrm{NP}_{\mathrm{S}}$ added in the culture medium at concentrations ranging from $10^{-6}$ to $10^{-4} \mathrm{M}$ the comparison of the impact of $10^{-4} \mathrm{M}$ of calcined iron $\mathrm{NP}_{\mathrm{S}}$ and dried iron $\mathrm{NP}_{\mathrm{S}}$ was assessed. In the third experiment, the recycling of calcined iron $\mathrm{NP}_{\mathrm{S}}$ was carried out for 2 further cultures in order to test their effect on the long term. 


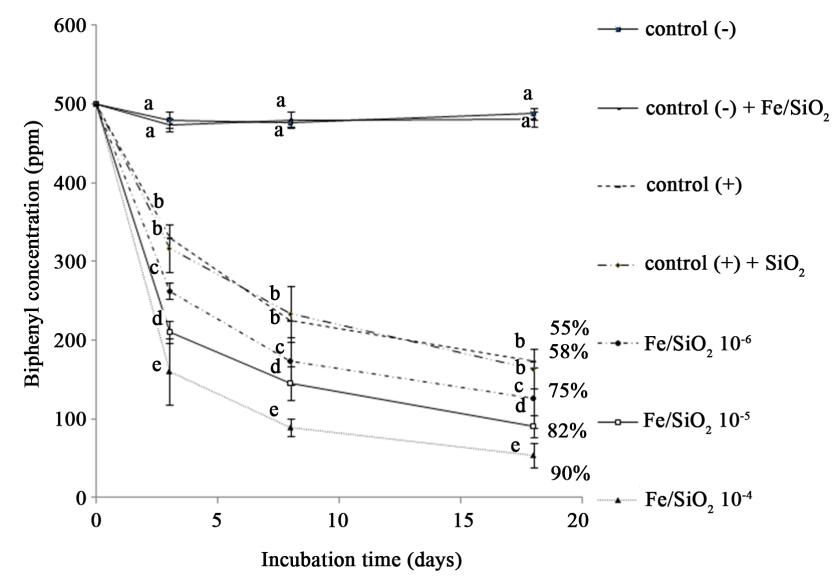

(a)

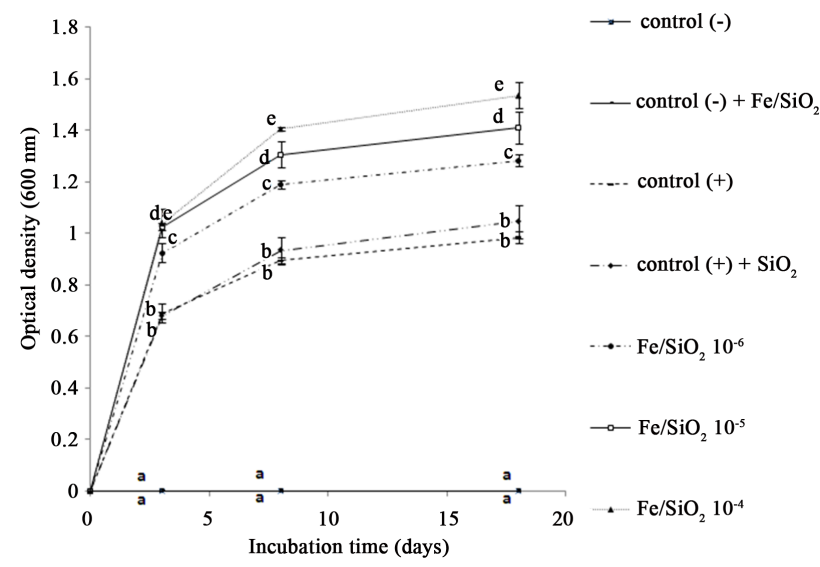

(b)

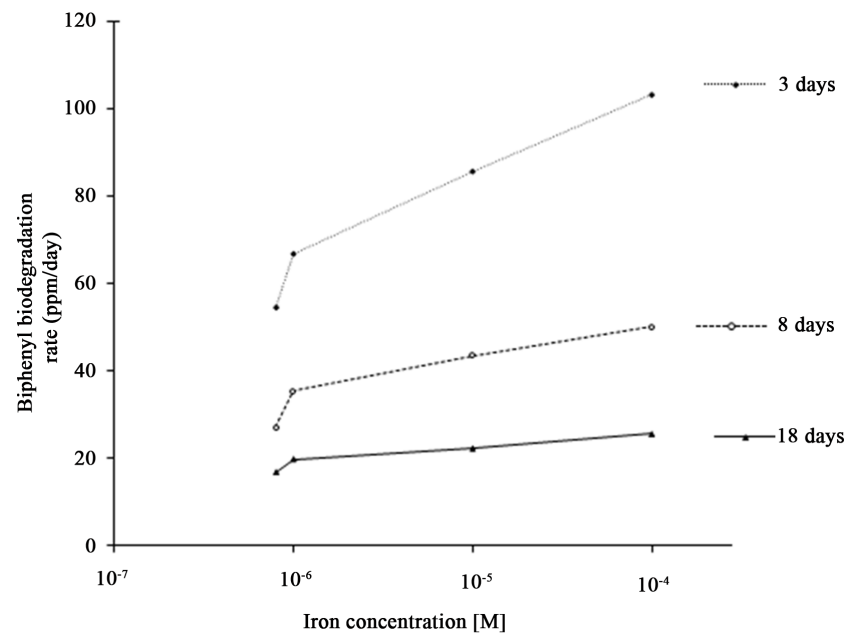

(c)

Figure 1. Evolution of biphenyl biodegradation by Rhodococcus erythropolis T902.1 in $100 \mathrm{~mL}$ flasks containing $20 \mathrm{~mL}$ of M284 minimal medium, 500 ppm biphenyl and different concentrations of calcined iron nanoparticles from $10^{-6}$ to $10^{-4} \mathrm{M}$ : (a) biphenyl concentration; (b) growth measured by optical density at $600 \mathrm{~nm}$; (c) biphenyl biodegradation rate after 3,8 and 18 days of culture. Control $(-)$ and control $(-)+\mathrm{Fe} / \mathrm{SiO}_{2}$ were carried out without microorganisms, control (+) without $\mathrm{NP}_{\mathrm{S}}$ nor $\mathrm{SiO}_{2}$, control $(+)+\mathrm{SiO}_{2}$ without $\mathrm{NP}_{\mathrm{S}}$. The similar letters (aa, bb, cc, dd and ee) indicate that no significant statistical differences were observed ( $p$-value > $0.05)$ at different time points of biphenyl biodegradation by RT902.1. 


\subsection{Effect of $\mathrm{NP}_{\mathrm{S}}$ Concentration}

Figure 1(a) and Figure 1(b) show that the presence of iron $\mathrm{NP}_{\mathrm{S}}$ without inoculum did not exhibit any effect on the degradation of biphenyl when compared to the negative control without $\mathrm{Fe} / \mathrm{SiO}_{2} \mathrm{NP}_{\mathrm{S}}$ at all time points $(p>$ 0.05). It suggests that the presence of different iron $\mathrm{NP}_{\mathrm{S}}$ concentrations in the absence of bacteria did not contribute to an abiotic mechanism of biphenyl degradation. By comparison, Lipczynska-Kochany et al. [34] reported that the addition of iron $\left(\mathrm{Fe}^{0}\right)$ without inoculum exhibits abiotic effect on the degradation of carbon tetrachloride. This effect was increased in the presence of sulphur compounds such as sodium sulphate, sodium sulphide, and ferrous sulphide. However, such abiotic effect on partial degradation and/or bioavailability improvement of complex molecules for further biodegradation was mainly reported for halogenated compounds [16] [34]. Moreover the abiotic effect would not be effective in our experimentations because the biphenyl is insoluble in the culture medium and iron $\mathrm{NP}_{\mathrm{S}}$ are encapsulated inside the porous silica matrix [27] preventing a direct contact with each other. By contrast, the present study shows that biphenyl concentration decreases with RT902.1 growth (measured by OD at $610 \mathrm{~nm}$ ) and that the biodegradation rate increases with increasing the Fe/ $\mathrm{SiO}_{2}$ concentration (Figure 1). Iron $\mathrm{NP}_{\mathrm{S}}$ at the concentration of $10^{-4} \mathrm{M}$ significantly influenced the biphenyl biodegradation efficiency when compared to the concentration of $10^{-5} \mathrm{M}$ and $10^{-6} \mathrm{M}(p<0.05)$ since biphenyl biodegradation yields up to $90 \%, 82 \%$ and $75 \%$ respectively after 18 days of incubation (Figure 1(a)).

Figure 1(c) also shows that the biphenyl degradation rate increases significantly (i.e. by about $30 \%$ ) at day 3 when adding $10^{-6} \mathrm{M}$ of iron $\mathrm{NP}_{\mathrm{S}}$ to the culture medium already containing $7 \times 10^{-7} \mathrm{M}$ iron ammonium citrate and, during the exponential growth phase (i.e. results recorded at 3 days of incubation), this rate increases logarithmically with increasing $\mathrm{NP}_{\mathrm{S}}$ concentration. As a consequence, since the presence of $10^{-4} \mathrm{M} \mathrm{Fe} / \mathrm{SiO}_{2}$ lead to biphenyl degradation rate about 2 fold higher than in the positive control it was therefore unfavorable for further industrial application to test higher $\mathrm{NP}_{\mathrm{S}}$ concentrations. Rapid tests up to $2 \times 10^{-3} \mathrm{M} \mathrm{Fe} / \mathrm{SiO}_{2}$ did not achieved higher biodegradation yields after 18 days of incubation (results not shown).

The decrease of biphenyl biodegradation rate after three days of culture, regardless of the concentration of $\mathrm{NP}_{\mathrm{S}}$ (Figure 1(c)) should be related with the release of soluble metabolites, which gives a yellow color to the medium [35]. HPLC analysis of the aqueous phase of the culture medium revealed the presence of two compounds identified as catechol and benzoic acid (Table 1) (retention time of $4.3 \mathrm{~min}$ and $7.9 \mathrm{~min}$ respectively). Benzoic acid concentration increased regularly whereas catechol appeared in the culture during the growth phase and disappeared during the stationary phase. These compounds were already identified with the Micrococcus species and Rhodococcus species in the presence of biphenyl as the sole source of carbon [36] [37]. Since the yellow color appeared with RT902.1 growth on biphenyl and disappeared after about 12 days of incubation, the analysis of the carbon mass balance considering this substrate and the major metabolites (Table 1) indicates that biphenyl is partially metabolized by RT902.1. This result is in agreement with Bevinakatti and Ninnekar [36] who showed that the culture medium became yellow colored during growth of Micrococcus, indicating that the biphenyl was metabolized by this strain. Additionally, Kuony [35] also reported the production of yellow compounds without increasing the bacterial density, indicating that the aromatic hydrocarbons (fluorene and fluoranthene) were partially metabolized by Mycobacterium sp. 6py1.

Table 1. Evolution of benzoic acid and catechol production from biphenyl biodegradation (500 ppm initial concentration) by Rhodococcus erythropolis T902.1 cultured for 18 days in $100 \mathrm{~mL}$ flasks containing $20 \mathrm{~mL}$ of M284 minimal medium with or without $10^{-4} \mathrm{M}$ of calcined iron $\mathrm{NP}_{\mathrm{S}}$.

\begin{tabular}{|c|c|c|c|}
\hline \multirow[b]{2}{*}{ Incubation time } & \multicolumn{3}{|c|}{ Metabolites concentration (ppm) } \\
\hline & 3 days & 8 days & 18 days \\
\hline \multicolumn{4}{|l|}{ Catechol } \\
\hline Positive control & $66.14 \pm 0.09$ & $33.00 \pm 0.07$ & $19.40 \pm 0.08$ \\
\hline Culture with $\mathrm{Fe} / \mathrm{SiO}_{2} 10^{-4} \mathrm{M}$ & $74.38 \pm 0.06$ & $43.36 \pm 0.09$ & $24.50 \pm 0.03$ \\
\hline \multicolumn{4}{|l|}{ Benzoic acid } \\
\hline Positive control & $1.19 \pm 0.10$ & $3.09 \pm 0.35$ & $13.39 \pm 0.96$ \\
\hline Culture with $\mathrm{Fe} / \mathrm{SiO}_{2} 10^{-4} \mathrm{M}$ & $4.36 \pm 0.14$ & $10.30 \pm 0.21$ & $25.39 \pm 0.92$ \\
\hline
\end{tabular}




\subsection{Effect of Dried or Calcined NPS}

The impact of $10^{-4} \mathrm{M} \mathrm{Fe} / \mathrm{SiO}_{2}$ calcined $\mathrm{NP}_{\mathrm{S}}$ on biphenyl biodegradation was compared with similar $\mathrm{NP}_{\mathrm{S}}$ that did not undergo the calcination step. Therefore the iron $\mathrm{NP}_{\mathrm{S}}$ were still complexed between the acetyl acetonate andtetraethoxysilane molecules [27] whereas the calcined iron $\mathrm{NP}_{\mathrm{S}}$ are in the form of metallic oxide $\left(\mathrm{Fe}_{\mathrm{x}} \mathrm{O}_{\mathrm{y}}\right)$ [38].

Figure 2(a) and Figure 2(b) shows that dried or calcined iron $\mathrm{NP}_{\mathrm{S}}$ achieved similar improvement effect on biphenyl biodegradation (90\% or 91\%). These results confirm that iron $\mathrm{NP}_{\mathrm{s}}$, whatever reduced, complexed or oxidized have a positive impact on the potential of RT902.1. They are consistent with those reported by Ansari et al. [15] about dibenzothiophene biodesulfurization carried out by Rhodococcus erythropolis IGST8 decorated

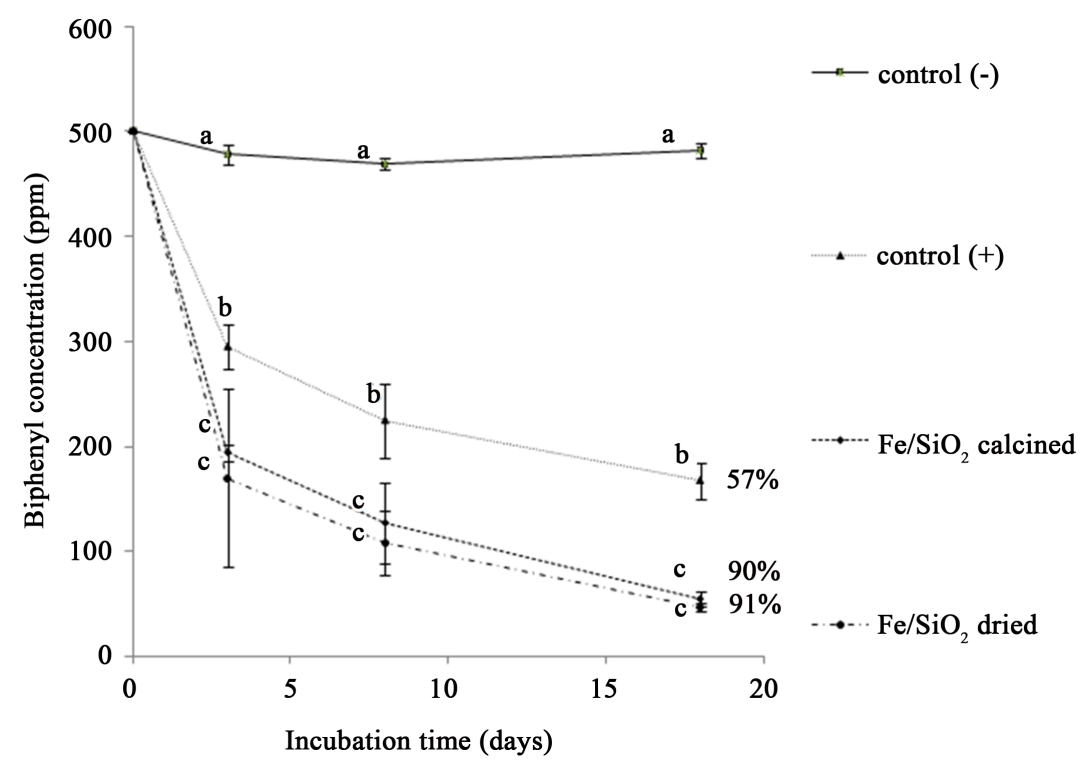

(a)

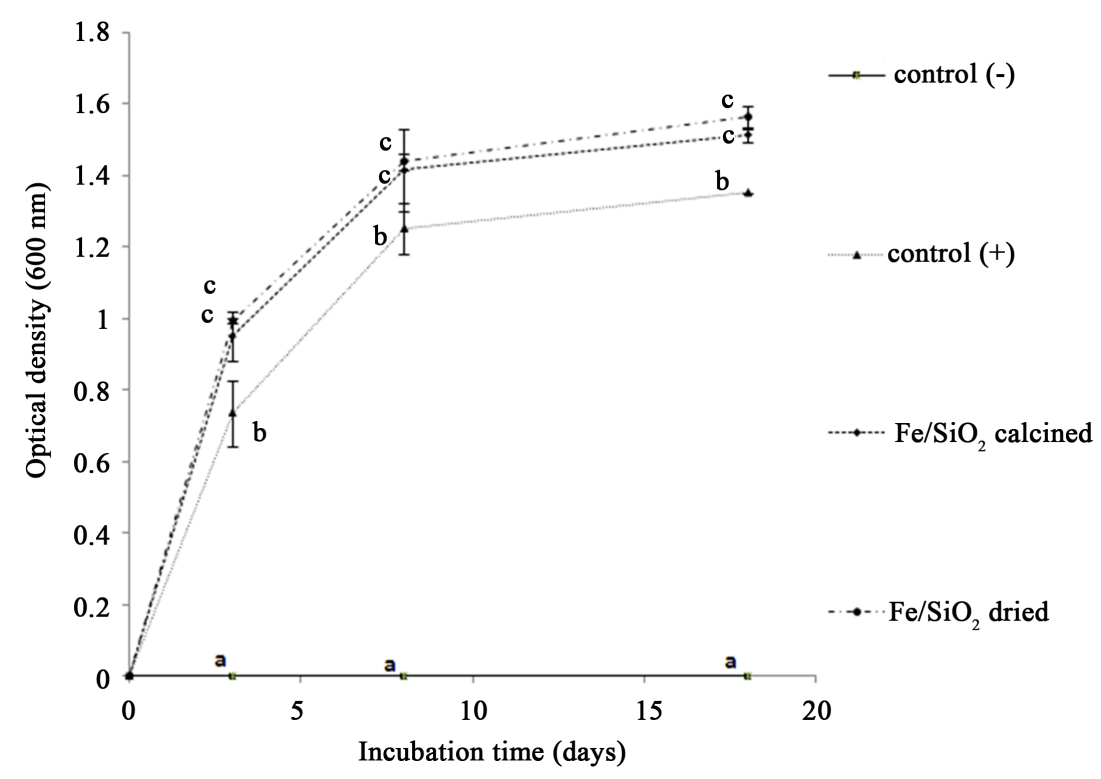

(b)

Figure 2. Evolution of biphenyl biodegradation by Rhodococcus erythropolis T902.1 in $100 \mathrm{~mL}$ flasks containing $20 \mathrm{~mL}$ of M284 minimal medium, $500 \mathrm{ppm}$ biphenyl and $10^{-4} \mathrm{M}$ of calcined or dried iron nanoparticles: (a) biphenyl concentration and (b) growth measured by optical density at $600 \mathrm{~nm}$. The similar letters (aa, bb, and cc) indicate that no significant statistical differences were observed ( $p$-value $>0.05$ ) in the presence of $10^{-4} \mathrm{M}$ of calcined or dried iron nanoparticles. 
with $4 \times 10^{-4} \mathrm{M}$ of magnetic $\mathrm{Fe}_{3} \mathrm{O}_{4}$ nanoparticles. They achieved a 56\% higher desulfurization activity in basic salt medium than with the nondecorated cells. Olle et al. [39] also reported that the presence of $1 \mathrm{M}$ of colloidal dispersions of magnetite $\left(\mathrm{Fe}_{3} \mathrm{O}_{4}\right)$ improves cell density in bacterial cultures. Regarding the presence of iron complexed by potentially inhibiting-organic molecules such as acetyl acetonate and tetraethoxysilane in dried $\mathrm{Fe} / \mathrm{SiO}_{2}$, Bunescu et al. [3] reported that the presence of Fe(III)-nitrilotriacetic acid complex (FeNTA) increased the degradation of 2-aminobenzothiazol by Rhodococcus rhodochrous without any inhibition up to $5 \times 10^{-4} \mathrm{M}$ FeNTA.

\subsection{Effect of NPs Recycling}

Following the experiment with $10^{-4} \mathrm{M}$ calcined $\mathrm{Fe} / \mathrm{SiO}_{2} \mathrm{NP}_{\mathrm{S}}$, two cycles of culture (fresh inoculum) were carried out with the initial $10^{-4} \mathrm{M} \mathrm{NP}_{\mathrm{S}}$ recovered at the end of each culture by centrifugation and calcination to remove biomass. In parallel a similar procedure was applied to the supernatant of the cultures (without $\mathrm{NP}_{\mathrm{S}}$ ) but considering apotential additional concentration of soluble iron transferred from the $\mathrm{NP}_{\mathrm{s}}$. As seen in Table 2, the biphenyl degradation yield in presence of $\mathrm{Fe} / \mathrm{SiO}_{2} \mathrm{NP}_{\mathrm{S}}$ (pellet) decreased progressively with time (3 cycles during 64 days) from $90 \%$ to $84 \%$ and $82 \%$ respectively. Compared with Figure 1(a) this trend did not overtake the results with $10^{-5} \mathrm{M} \mathrm{NP}_{\mathrm{S}}$ (82\%). By contrast, the biphenyl degradation yield increased progressively in the different supernatants from the successive cultures with increase of available iron released from the capsule of $\mathrm{SiO}_{2}$. Indeed the concentration of iron in the supernatants increased from $2 \times 10^{-5} \mathrm{M} \pm 0.01$ to $6 \times 10^{-5} \mathrm{M} \pm 0.01$ respectively. The positive control (flasks with pellet and flasks with supernatant) showed similar biphenyl degradation yields and iron concentrations during the three cycles. Since, as measured by ICP-AES method [38], only $0.02 \%$ of the iron releases naturally from $\mathrm{NP}_{\mathrm{S}}$ in culture medium without microorganisms (probably due to some unstable $\mathrm{Fe} / \mathrm{SiO}_{2}$ capsules in autoclave), these results indicate that interactions should exist between the bacteria and the metallic encapsulated elements. Therefore iron would be attracted progressively from the capsule of $\mathrm{SiO}_{2}$. One can imagine that this mechanism is initiated for consumption of iron by the bacteria cells.

Table 2. Evolution of total iron concentration, biphenyl biodegradation yield in \% and growth measured by optical density of Rhodococcus erythropolis T902.1 after three successive cycles of 18 days of incubation in $100 \mathrm{~mL}$ flasks containing $20 \mathrm{~mL}$ of minimal medium and $500 \mathrm{ppm}$ biphenyl with or without $10^{-4} \mathrm{M}$ of calcined iron $\mathrm{NP}_{\mathrm{S}}$.

\begin{tabular}{|c|c|c|c|c|}
\hline \multicolumn{5}{|c|}{ First cycle } \\
\hline \multirow[t]{2}{*}{ Experience condition } & \multicolumn{2}{|c|}{ Culture with $\mathrm{Fe} / \mathrm{SiO}_{2} 10^{-4} \mathrm{M}$} & \multicolumn{2}{|c|}{ Positive control } \\
\hline & pellet & supernatant & pellet & supernatant \\
\hline Biphenyl biodegradation yield (\%) & 90 & 64 & 55 & 56 \\
\hline Optical density & $1.60 \pm 0.07$ & $0.85 \pm 0.04$ & $0.75 \pm 0.06$ & $0.73 \pm 0.07$ \\
\hline Total iron (M) & $9.210^{-5} \pm 0.01$ & $2.010^{-5} \pm 0.01$ & $610^{-6} \pm 0.01$ & $210^{-6} \pm 0.01$ \\
\hline \multicolumn{5}{|c|}{ Second cycle } \\
\hline \multirow[t]{2}{*}{ Experience condition } & \multicolumn{2}{|c|}{ Culture with $\mathrm{Fe} / \mathrm{SiO}_{2} 10^{-4} \mathrm{M}$} & \multicolumn{2}{|c|}{ Positive control } \\
\hline & pellet & supernatant & pellet & supernatant \\
\hline Biphenyl biodegradation yield (\%) & 84 & 65 & 58 & 57 \\
\hline Optical density & $1.54 \pm 0.09$ & $1 \pm 0.08$ & $0.76 \pm 0.06$ & $0.74 \pm 0.09$ \\
\hline Total iron (M) & $8.610^{-5} \pm 0.01$ & $3.010^{-5} \pm 0.03$ & $410^{-6} \pm 0.02$ & $310^{-6} \pm 0.01$ \\
\hline \multicolumn{5}{|c|}{ Third cycle } \\
\hline \multirow[t]{2}{*}{ Experience condition } & \multicolumn{2}{|c|}{ Culture with $\mathrm{Fe} / \mathrm{SiO}_{2} 10^{-4} \mathrm{M}$} & \multicolumn{2}{|c|}{ Positive control } \\
\hline & pellet & supernatant & pellet & supernatant \\
\hline Biphenyl biodegradation yield (\%) & 82 & 69 & 57 & 56 \\
\hline Optical density & $1.52 \pm 0.06$ & $1.00 \pm 0.09$ & $0.76 \pm 0.06$ & $0.75 \pm 0.07$ \\
\hline Total iron (M) & $8.1 \times 10^{-5} \pm 0.01$ & $6.0 \times 10^{-5} \pm 0.01$ & $5 \times 10^{-6} \pm 0.00$ & $3 \times 10^{-6} \pm 0.02$ \\
\hline
\end{tabular}




\subsection{Iron Distribution in the Different Compartments of RT902.1}

Iron concentration was measured in the different compartments of the biomass (extracellular, intracellular and at the cell surface) after 18 days of incubation (first cycle of the experiment of section "Effect of $\mathrm{NP}_{\mathrm{S}}$ recycling"). Table 3 shows that while the biomass was not totally similar in the cultures with $\mathrm{NP}_{\mathrm{S}}$ and the positive control, about $35 \%$ of the iron initially present in the $10^{-4} \mathrm{M} \mathrm{Fe} / \mathrm{SiO}_{2} \mathrm{NP}_{\mathrm{S}}$ was found in solution $\left(3.5 \times 10^{-5} \mathrm{M} \pm 0.01\right) \mathrm{a}$ similar content was adsorbed at the cell surface $\left(3.4 \times 10^{-5} \mathrm{M} \pm 0.01\right)$ and about $10 \%$ was considered intracellu$\operatorname{lar}\left(9 \times 10^{-6} \mathrm{M} \pm 0.01\right)$.

This distribution also enables to calculate that about $25 \%$ of the initial $10^{-4} \mathrm{M}$ iron $\mathrm{NP}_{\mathrm{S}}$ was still encapsulated after the first cycle and, assuming a similar distribution at each of the 3 cycles experimented in the section "Effect of $\mathrm{NP}_{\mathrm{S}}$ recycling", it can be estimated that about $35 \%$ of the iron was lost in each supernatant. Therefore the total iron content in the third cycle would reach $10^{-5} \mathrm{M}$ with a low residual iron amount in the $\mathrm{Fe} / \mathrm{SiO}_{2}$ catalyst. This is in accordance with the decreasing trend of biphenyl degradation yields in the successive cycles. To our knowledge, the literature does not report any precise answer about the metabolism of iron $\mathrm{NP}_{\mathrm{S}}$ during biphenyl biodegradation by Rhodococcus strains. These bacteria are not able to degrade $\mathrm{SiO}_{2}$ and the iron $\mathrm{NP}_{\mathrm{S}}$, with sizes of about $2-3 \mathrm{~nm}$, are embedded in inorganic microporous silica particles of around 10 to $20 \mathrm{~nm}$ diameter with pores not exceeding $1 \mathrm{~nm}$ diameter [24]. Therefore, Rhodococcus erythropolis cells cannot enter into the silicon dioxide matrix to directly catch the iron. As a consequence RT902.1 would produce specific microbial sensors such as siderophores in order to attract iron from the inside of the silicon dioxide microporous structure as suggested by some authors [40] [41]. This result is in agreement with Kasemets et al. [42] who proposed that since in the normal conditions $\mathrm{NP}_{\mathrm{S}}$ cannot enter the yeast cells, these cells would produce specific microbial sensors, for the internalization of nanoparticles. Kraemer [41] also showed that siderophore stimulated the solubility and dissolution kinetics of iron oxides in environments.

\subsection{Effect of NP on Major Enzymes Activity}

Regarding the reduction of iron, there are two main ways reported in the literature. First extracellularly, the flavin reductase reduces $\mathrm{Fe}^{3+}$ to $\mathrm{Fe}^{2+}$, then $\mathrm{Fe}^{2+}$ is transported by a specific membrane transporter into the cell [29]. In the second way, the $\mathrm{Fe}^{3+}$ is chelated by a siderophore that is integrated into the cell, where $\mathrm{Fe}^{3+}$ is reduced [43].

Intracellularly, an enzyme complex simultaneously reduces $\mathrm{Fe}^{3+}$ to $\mathrm{Fe}^{2+}$ and activates the enzymes which are responsible of the main steps of biphenyl biodegradation. Indeed, the structure of purified dioxygenase confirms the presence of Rieske cluster $\left\{{ }^{2} \mathrm{~F}^{2} \mathrm{~S}\right\}$ and $\mathrm{Fe}^{2+}$ on different sites. It could be inhibited when $\mathrm{Fe}^{2+}$ is oxidized in $\mathrm{Fe}^{3+}$ and reactivated by the addition of $\mathrm{Fe}^{2+}$ [44] [45]. Nadaf et al. [32] found that the enzymatic activity of catechol1,2dioxygenase was completely inhibited with addition of $10^{-3} \mathrm{M}$ of $\mathrm{Fe}^{3+}$. This study also confirms the $\mathrm{Fe}^{2+}$ form of the iron inside the cells. The dioxygenase activity assayed by indigo production from indole added to culture samples [46]. Figure 3(a) showed that the presence of $10^{-4} \mathrm{M} \mathrm{Fe} / \mathrm{SiO}_{2} \mathrm{NP}_{\mathrm{S}}$ has a positive impact on the enzyme. Indeed, the enzyme activity achieved a specific rate of $0.016 \mathrm{mg}$ indigo/mg protein $/ \mathrm{min}$ after 48 hours of incubation compared to the $0.01 \mathrm{mg}$ indigo/mg protein/min in the positive control, then it decreased dramatically until the end of the experiments (75 hours of incubation). Similarly Figure 3(b) suggests that Fe/

Table 3. Iron concentration in the different compartments of Rhodococcus erythropolis T902.1 cells (extracellular, intracellular and at the cell surface) after 18 days of incubation in $100 \mathrm{~mL}$ flasks containing $20 \mathrm{~mL}$ of M284 minimal medium, 500 ppm biphenyl and $10^{-4} \mathrm{M}$ of calcined iron $\mathrm{NP}_{\mathrm{S}}$ (first cycle).

\begin{tabular}{cccc}
\hline & & Iron concentration (M) & \\
\hline Experience condition & Soluble extracellular & Absorbed at cell surface & Intracellular \\
\hline Positive control & $8.1 \times 10^{-6} \pm 0.01$ & $5.4 \times 10^{-6} \pm 0.01$ & $6.7 \times 10^{-6} \pm 0.01$ \\
Culture with $\mathrm{Fe} / \mathrm{SiO}_{2} 10^{-4} \mathrm{M}$ & $4.3 \times 10^{-5} \pm 0.01$ & $3.9 \times 10^{-5} \pm 0.01$ & $1.6 \times 10^{-5} \pm 0.01$ \\
& Iron released from the $\mathrm{SiO}_{2}$ capsule & $9 \times 10^{-6} \pm 0.01$ \\
Molar unit & $3.5 \times 10^{-5} \pm 0.01$ & $3.4 \times 10^{-5} \pm 0.01$ & 9.5 \\
\hline
\end{tabular}




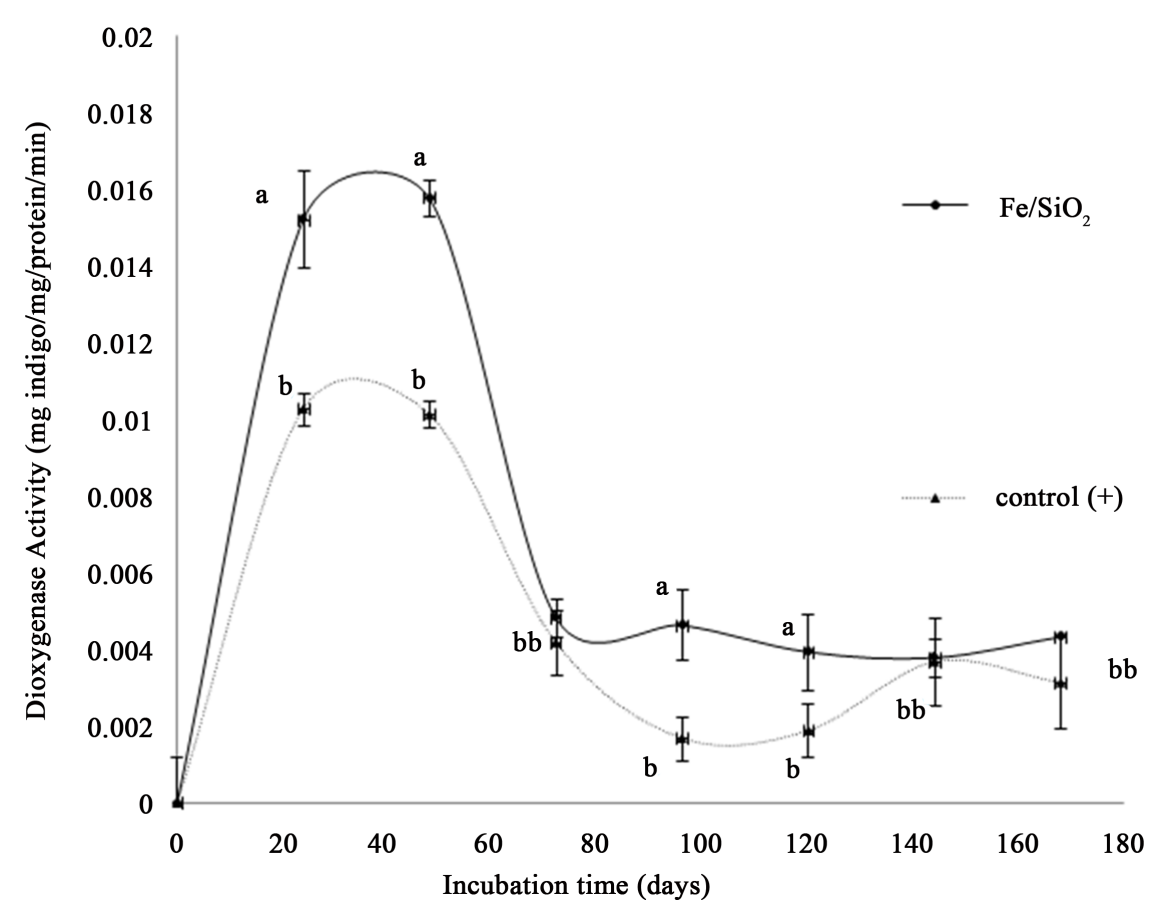

(a)

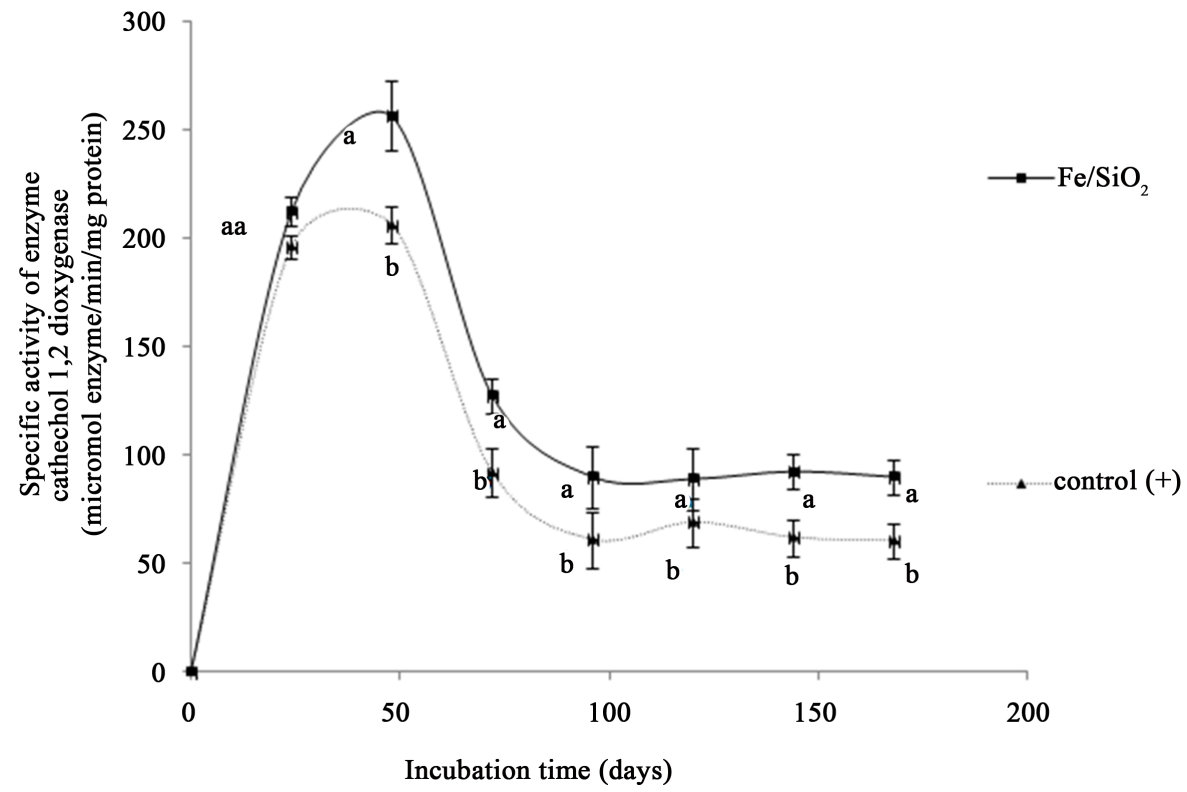

(b)

Figure 3. Evolution of biphenyl biodegradation by Rhodococcus erythropolis T902.1 in 100 $\mathrm{mL}$ flasks containing $20 \mathrm{~mL}$ of M284 minimal medium, $500 \mathrm{ppm}$ biphenyl and $10^{-4} \mathrm{M}$ of calcined iron nanoparticles: (a) Biphenyl dioxygenase activity defined as the rate of indigo formation per mg protein and (b) 1,2catechol dioxygenase specific activity versus time. The similar letters indicate that no significant statistical differences were observed between the two curves ( $p$-value $>0.05)$.

$\mathrm{SiO}_{2}$ stimulates the catechol1,2dioxygenase activity $(p<0.05)$. These results are consistent with those of Yeom and Yoo [7] and Dinkla et al. [47] who showed that the activity of the enzymes responsible of the biodegradation of pollutants increased after the addition of iron in the culture medium. It should also be mentioned that the 
higher cell density achieved in presence of iron $\mathrm{NP}_{\mathrm{S}}$ or the higher iron availability for the microorganisms could lead to higher biphenyl bioavailability through an improved production of biosurfactants that are often mentioned in the literature regarding hydrocarbons biodegradation by Rhodococcus strains [48].

\section{Conclusion}

In conclusion, the results of this study have shown that the biphenyl biodegradation by RT902.1 is improved in the presence of the iron $\mathrm{NP}_{\mathrm{S}}$ encapsulated in porous silica. This improvement was found to be dependent on the $\mathrm{Fe} / \mathrm{SiO}_{2}$ concentration but not on the iron form whatever calcined as iron oxide or simply dried as iron complex with organic compounds. The highest biodegradation performance with a 35\% higher biphenyl degradation yield was recorded with $10^{-4} \mathrm{M}$ of iron $\mathrm{NP}_{\mathrm{S}}$ than in the control conditions without $\mathrm{NP}_{\mathrm{s}}$. The performance increase is mainly recorded in exponential growth phase with a logarithmic increase of biphenyl degradation rate with increase of iron $\mathrm{NP}_{\mathrm{S}}$ concentration from $10^{-6}$ to $10^{-4} \mathrm{M}$. It was also shown that the positive effect of $10^{-4} \mathrm{M}$ $\mathrm{Fe} / \mathrm{SiO}_{2} \mathrm{NP}_{\mathrm{S}}$ was related to a higher enzyme activity since the biphenyl dioxygenase and catechol1,2dioxygenase reached an about $50 \%$ and $25 \%$ higher maximum activity respectively. In addition, the analysis of the iron distribution showed that about $10 \%$ and $35 \%$ of the initial $10^{-4} \mathrm{M}$ iron $\mathrm{NP}_{\mathrm{S}}$ encapsulated in the $\mathrm{SiO}_{2}$ matrix would be incorporated inside or adsorbed on the cell surface and $35 \%$ would be released in the supernatant. These results suggest that RT902.1 would produce siderophore-like molecules to attract iron from the porous silica matrix.

\section{Acknowledgements}

W. W. is grateful for Damascus University-Syria for their grant supported correspondence. S. D. L. is grateful to F.R.S.-F.N.R.S for her research associate position. T. M. is also grateful to F.R.I.A for his Ph.D. thesis grant. The authors are grateful to Dr Nassim Moula for his contribution on statistical analyses in this study. The authors acknowledge the Ministry of the Walloon Region General Directorate of Technology, Resherch and Energy and the Fonds de Recherche Fondamentale Collective for financial supports.

\section{References}

[1] Indu Nair, C., Jayachandran, K. and Shashidhar, S. (2008) Biodegradation of Phenol. African Journal of Biotechnology, 7, 4951-4958.

[2] Watanabe, K. (2001) Microorganisms Relevant to Bioremediation. Current Opinion in Biotechnology, 12, $231-241$. http://dx.doi.org/10.1016/S0958-1669(00)00205-6

[3] Bunescu, A., Besse-Hoggan, P., Sancelme, M., Mailhot, G. and Delort, A.M. (2008) Comparison of Microbial and Photochemical Processes and Their Combination for Degradation of 2-Aminobenzothiazole. Applied and Environmental Microbiology, 74, 2976-2984.

[4] De Windt, W., Aelterman, P. and Verstraete, W. (2005) Bioreductive Deposition of Palladium (0) Nanoparticles on Shewanella oneidensis with Catalytic Activity towards Reductive Dechlorination of Polychlorinated Biphenyls. Journal of Environmental Microbiology, 7, 314-325. http://dx.doi.org/10.1111/j.1462-2920.2005.00696.x

[5] Mergeay, M., Nies, D., Schlegel, H.G., Gerits, J., Charles, P. and van Gijsegem, F. (1985) Alcaligenes eutrophus CH34 Is a Facultative Chemolithotroph with Plasmid-Bound Resistance to Heavy Metals. Journal of Bacteriology, 162, 328334.

[6] Sterritt, R.M. and Lester, J.N. (1980) Interactions of Heavy Metals with Bacteria. Science of the Total Environment, 14, 5-17. http://dx.doi.org/10.1016/0048-9697(80)90122-9

[7] Yeom, S.H. and Yoo, Y.J. (1997) Overcoming the Inhibition Effects of Metal Ions in the Degradation of Benzene and Toluene by Alcaligenes xylosoxidans y234. Korean Journal of Chemical Engineering, 14, 204-208. http://dx.doi.org/10.1007/BF02706096

[8] Chun-Wei, K. and Barbara, R.S.G. (1996) Effect of Added Heavy Metal Ions 3-Chlorobenzoate in Anaerobic Bacterial Consortia. Applied and Environmental Microbiology, 62, 2317-2323.

[9] Kotresha, D. and Vidyasagar, G.M. (2008) Isolation and Characterization of Phenol Degrading Pseudomonas aeruginosa MTCC 4996. World Journal of Microbiology Biotechnology, 24, 541-547. http://dx.doi.org/10.1007/s11274-007-9508-2

[10] Lin, C.W., Chen, S.Y. and Cheng, Y.W. (2006) Effect of Metals on Biodegradation Kinetics for Methyl tert-Butylether. Biochemical Engineering Journal, 32, 25-32. http://dx.doi.org/10.1016/j.bej.2006.07.010 
[11] Nies, D.H. (1999) Microbial Heavy-Metal Resistance. Applied Microbiology and Biotechnology, 51, 730-750. http://dx.doi.org/10.1007/s002530051457

[12] Santos, E.C., Jacques, R.J.S., Bento, F.M., Peralba, M.C.R., Selbach, P.A., Sa, E.L. and Camargo, F.A. (2008) Anthracene Biodegradation and Surface Activity by an Iron-Stimulated Pseudomonas sp. Bioresource Technology, 99, 2644-2649. http://dx.doi.org/10.1016/j.biortech.2007.04.050

[13] Chorao, C. (2008) Investigation of Rhodococcus rhodochrous Metabolism in Photo- and Bio-Degradation of 2-aminobenzothiazol: Effect of Cell Immobilisation and Role of Iron. Ph.D Thesis of University Blaise Pascal, Clermont-Ferrand. http://tel.archives-ouvertes.fr/tel-00731145

[14] Zhang, W.X. (2003) Nanoscale Iron Particles for Environmental Remediation: An Overview. Journal of Nanoparticle Research, 5, 323-332. http://dx.doi.org/10.1023/A:1025520116015

[15] Ansari, F., Grigoriev, P., Libor, S., Tothill, I.E. and Ramsden, J.J. (2008) DBT Degradation Enhancement by Decorating Rhodococcus erythropolis IGST8 with Magnetic $\mathrm{Fe}_{3} \mathrm{O}_{4}$ Nanoparticles. Biotechnology and Bioengineering, 102, 1505-1512. http://dx.doi.org/10.1002/bit.22161

[16] Murugesan, K., Bokare, V., Jeon, J.R., Kim, E.J., Kim, J.H. and Chang, Y.S. (2011) Effect of Fe-Pd Bimetallic Nanoparticles on Sphingomonas sp. PH-07 and a Nano-Bio Hybrid Process for Triclosan Degradation. Bioresource Technology, 102, 6019-6025. http://dx.doi.org/10.1016/j.biortech.2011.02.099

[17] Choi, M., Biswas, P., Fissan, H. and Pui, D.Y.H. (2003) Special Issue on Nanoparticles: Technology and Sustainabl Development. Journal of Nanoparticle Research, 5, 2-3.

[18] Wagner, S., Munzer, S., Behrens, P., Scheper, T., Bahnemann, D. and Kasper, C. (2009) Cytotoxicity of Titanium and Silicon Dioxide Nanoparticles. Journal of Physics: Conference Series, 170, $12-22$.

[19] Pal, S., Tak, Y.K. and Song, J.M. (2007) Does the Antibacterial Activity of Silver Nanoparticles Depend on the Shape of the Nanoparticle? A Study of the Gram-Negative Bacterium Escherichia coli. Applied and Environmental Microbiology, 73, 1712-1720. http://dx.doi.org/10.1128/AEM.02218-06

[20] Panyala, N.R., Pena-Mendez, E.M. and Havel, J. (2008) Silver or Silver Nanoparticles: A Hazardous Threat to the Environment and Human Health. Journal of Applied Biomedicine, 6, 117-129.

[21] Beckers, L., Hiligsmann, S., Lambert, S., Heinrichs, B. and Thonart, P. (2013) Improving Effect of Metal and Oxide Nanoparticles Encapsulated in Porous Silica on Fermentative Biohydrogen Production by Clostridium butyricum. Bioresource Technology, 133, 109-117. http://dx.doi.org/10.1016/j.biortech.2012.12.168

[22] Lambert, S., Polard, J.F., Pirard, J.P. and Heinrichs, B. (2004) Improvement of Metal Dispersion in $\mathrm{Pd} / \mathrm{SiO}_{2} \mathrm{Cogelled}$ Xerogel Catalysts for 1, 2-dichloroethane Hydrodechlorination. Applied Catalysis B: Environmental, 50, 127-140. http://dx.doi.org/10.1016/j.apcatb.2004.01.015

[23] Lambert, S., Cellier, C., Grange, P., Pirard, J.P. and Heinrichs, B. (2004) Synthesis of Pd/SiO $\mathrm{S}_{2} \mathrm{Ag} / \mathrm{SiO}_{2}$, and Cu/SiO Cogelled Xerogel Catalysts: Study of Metal Dispersion and Catalytic Activity. Journal of Catalysis, 221, 335-346. http://dx.doi.org/10.1016/j.jcat.2003.07.014

[24] Lambert, S., Alie, C., Pirard, J.P. and Heinrichs, B. (2004) Study of Textural Properties and Nucleation Phenomenon in $\mathrm{Pd} / \mathrm{SiO}_{2}, \mathrm{Ag} / \mathrm{SiO}_{2}$ and $\mathrm{Cu} / \mathrm{SiO}_{2}$ Cogelled Xerogel Catalysts. Journal of Non-Crystalline Solids, 342, 70-81. http://dx.doi.org/10.1016/j.jnoncrysol.2004.06.005

[25] Marimuthu, T., Mohamad, S. and Alias, Y. (2014) Synthesis and Characterization of New Silica-Titania Mixed Oxide in the Presence of 1-butyl-3-methylimidazolium bis(trifluoromethylsulfonyl) Imide by Sol-Gel Technique. Journal of Sol-Gel Science and Technology, 70, 104-110. http://dx.doi.org/10.1007/s10971-014-3279-7

[26] Kaiser, A., Gorsmann, C. and Schubert, U. (1997) Influence of the Metal Complexation on Size and Composition of $\mathrm{Cu} / \mathrm{Ni}$ Nano-Particles Prepared by Sol-Gel Processing. Journal of Sol-Gel Science and Technology, 8, 795-799. http://dx.doi.org/10.1007/BF02436940

[27] Heinrichs, B., Rebbouh, L., Geus, J.W., Lambert, S., Abbenhuis, H.C.L., Grandjean, F., Long, G.J., Pirard, J.P. and van Santen, R.A. (2008) Iron(III) Species Dispersed in Porous Silica through Sol-Gel Chemistry. Journal of NonCrystalline Solids, 354, 665-672. http://dx.doi.org/10.1016/j.jnoncrysol.2007.07.071

[28] Weekers, F., Jacques, P., Springael, D., Mergeay, M., Diels, L. and Thonart, Ph. (1999) Improving the Catabolic Functions of Desiccation-Tolerant Soil Bacteria. Applied Biochemistry and Biotechnology, 77, 251-266. http://dx.doi.org/10.1385/ABAB:77:1-3:251

[29] Bunescu, A. (2006) Photo- and Bio-Degradation of Benzothiazole Compounds: Investigation of Combined Systems. Ph.D Thesis of University Blaise Pascal, Clermont-Ferrand. http://tel.archivesouvertes.fr/tel-00713567

[30] Bezkorovainy, A., Miller-Catchpole, R., Poch, M. and Solberg, L. (1986) The Mechanism of Iron Binding by Suspensions of Bifidobacterium bifidum var. Pennsylvanicus. Biochimica et Biophysica Acta (BBA)-General Subjects, 884, 60-66. http://dx.doi.org/10.1016/0304-4165(86)90227-8 
[31] O’Connor, K.E., Dobson, A.D. and Hartmans, S. (1997) Indigo Formation by Microorganisms Expressing Styrene Monooxygenase Activity. Applied and Environmental Microbiology, 63, 4287-4291.

[32] Nadaf, N.H. and Ghosh, J.S. (2011) Purification and Characterization of Catechol 1,2-dioxygenase from Rhodococcus sp. NCIM 2891. Research Journal of Environmental and Earth Sciences, 3, 608-613.

[33] Bradford, M.M. (1976) A Rapid and Sensitive Method for the Quantitation of Microgram Quantities of Protein Utilizing the Principle of Protein-Dye Binding. Analytical Biochemistry, 72, 248-254. http://dx.doi.org/10.1016/0003-2697(76)90527-3

[34] Lipczynska-Kochany, E., Harms, S., Milburn, R., Sprah, G. and Nadarajah, N. (1994) Degradation of Carbon Tetrachloride in the Presence of Iron and Sulphur Containing Compounds. Chemosphere, 29, 1477-1489. http://dx.doi.org/10.1016/0045-6535(94)90279-8

[35] Kuony, S. (2005) Caracterisation of Arene Dioxygenase Involved in Biodegradation of Polycyclic Aromatic Hydrocarbons by Mycobacterium sp. 6pyl. Ph.D. Thesis, University Joseph Fourier, Grenoble. http://tel.archives-ouvertes.fr/tel-00009997

[36] Bevinakatti, B.G. and Ninnekar, H.Z. (1992) Degradation of Biphenyl by a Micrococcus Species. Applied Microbiology and Biotechnology, 38, 273-275. http://dx.doi.org/10.1007/BF00174482

[37] Takeda, H., Yamada, A., Miyauchi, K., Masai, E. and Fukuda, M. (2004) Characterization of Transcriptional Regulatory Genes for Biphenyl Degradation in Rhodococcus sp. Strain RHA1. Journal of Bacteriology, 186, 2134-2146. http://dx.doi.org/10.1128/JB.186.7.2134-2146.2004

[38] Mahy, J.G., Tasseroul, L., Zubiaur, A., Geens, J., Brisbois, M., Herlitschke, M., Hermann, R., Heinrichs, B. and Lambert, S.D. (2014) Highly Dispersed Iron Xerogel Catalysts for p-Nitrophenol Degradation by Photo-Fenton Effects. Microporous and Mesoporous Materials, 197, 164-173. http://dx.doi.org/10.1016/j.micromeso.2014.06.009

[39] Olle, B., Bucak, S., Holmes, T.C., Bromberg, L., Hatton, T.A. and Wang, D.I.C. (2006) Enhancement of Oxygen Mass Transfer Using Functionalized Magnetic Nanoparticles. Industrial \& Engineering Chemistry Research, 45, 4355-4363. http://dx.doi.org/10.1021/ie051348b

[40] Carrano, C.J., Jordan, M., Drechsel, H., Schmid, D.G. and Winkelmann, G. (2001) Heterobactins: A New Class of Siderophores from Rhodococcus erythropolis IGTS8 Containing both Hydroxamate and Catecholate Donor Groups. Biometals, 14, 119-125. http://dx.doi.org/10.1023/A:1016633529461

[41] Kraemer, S.M. (2004) Iron Oxide Dissolution and Solubility in the Presence of Siderophores. Aquatic Sciences, 66, 3-18. http://dx.doi.org/10.1007/s00027-003-0690-5

[42] Kasemets, K., Ivask, A., Dubourguier, H.C. and Kahru, A. (2009) Toxicity of Nanoparticles of $\mathrm{ZnO} \mathrm{CuO}_{\text {and }} \mathrm{TiO}_{2}$ to Yeast Saccharomyces cerevisiae. Toxicology in Vitro, 23, 1116-1122. http://dx.doi.org/10.1016/j.tiv.2009.05.015

[43] Pierre, J.L., Fontecave, M. and Crichton, R.R. (2002) Chemistry for an Essential Biological Process: The Reduction of Ferric Iron. Biometals, 15, 341-346. http://dx.doi.org/10.1023/A:1020259021641

[44] Candidus, S., Van Pee, K.H. and Ligens, F. (1994) The Catechol 2,3-dioxygenase Gene of Rhodococcus rhodochrous CTM: Nucleotide Sequence, Comparison with Isofunctional Dioxygenases and Evidences for an Active-Site Histidine. Microbiology, 140, 321-330. http://dx.doi.org/10.1099/13500872-140-2-321

[45] Furusawa, Y., Nagarajan, V., Tanokura, M., Masai, E., Fukuda, M. and Senda, T. (2004) Crystal Structure of the Terminal Oxygenase Component of Biphenyl Dioxygenase Derived from Rhodococcus sp. Strain RHA1. Journal of Molecular Biology, 342, 1041-1052. http://dx.doi.org/10.1016/j.jmb.2004.07.062

[46] Zaki, S. (2006) Detection of Meta- and Ortho-Cleavage Dioxygenases in Bacterial Phenol-Degraders. Journal of Applied Sciences and Environmental Management, 10, 75-81.

[47] Dinkla, I.J.T., Gabor, E.M. and Janssen, D.B. (2001) Effects of Iron Limitation on Degradation of Toluene by Pseudomonas Strains Carrying the TOL (pWWO) Plasmid. Applied and Environmental Microbiology, 67, 3406-3412. http://dx.doi.org/10.1128/AEM.67.8.3406-3412.2001

[48] Zheng, C., Huang, L., Xiu, J.L. and Huang, Z.Y. (2012) Investigation of a Hydrocarbon-Degrading Strain, Rhodococcus ruber Z25 for the Potential of Microbial Enhanced Oil Recovery. Journal of Petroleum Science and Engineering, 81, 49-56. http://dx.doi.org/10.1016/j.petrol.2011.12.019 
Scientific Research Publishing (SCIRP) is one of the largest Open Access journal publishers. It is currently publishing more than 200 open access, online, peer-reviewed journals covering a wide range of academic disciplines. SCIRP serves the worldwide academic communities and contributes to the progress and application of science with its publication.

Other selected journals from SCIRP are listed as below. Submit your manuscript to us via either submit@scirp.org or Online Submission Portal.
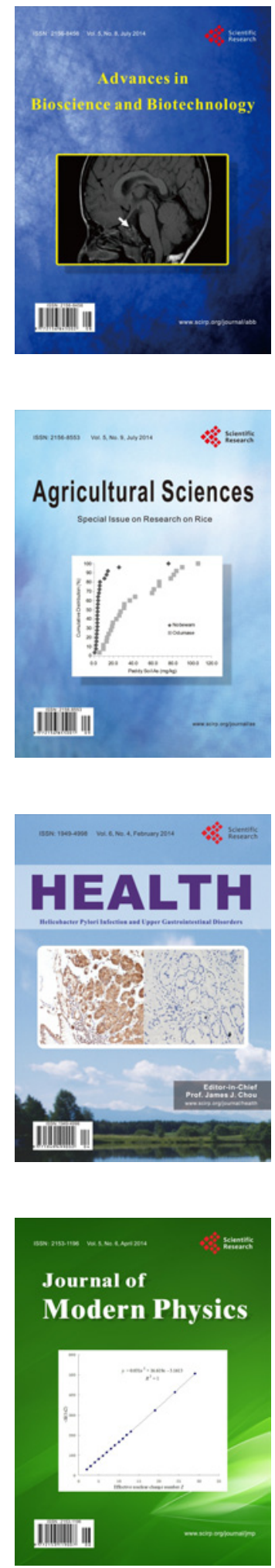
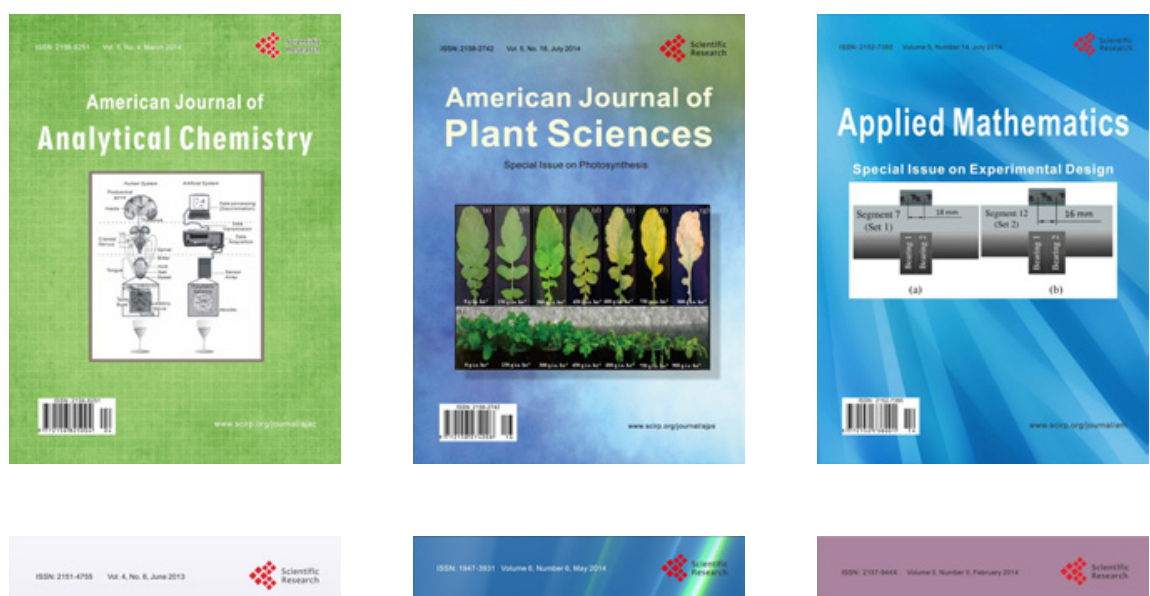

Creative Education
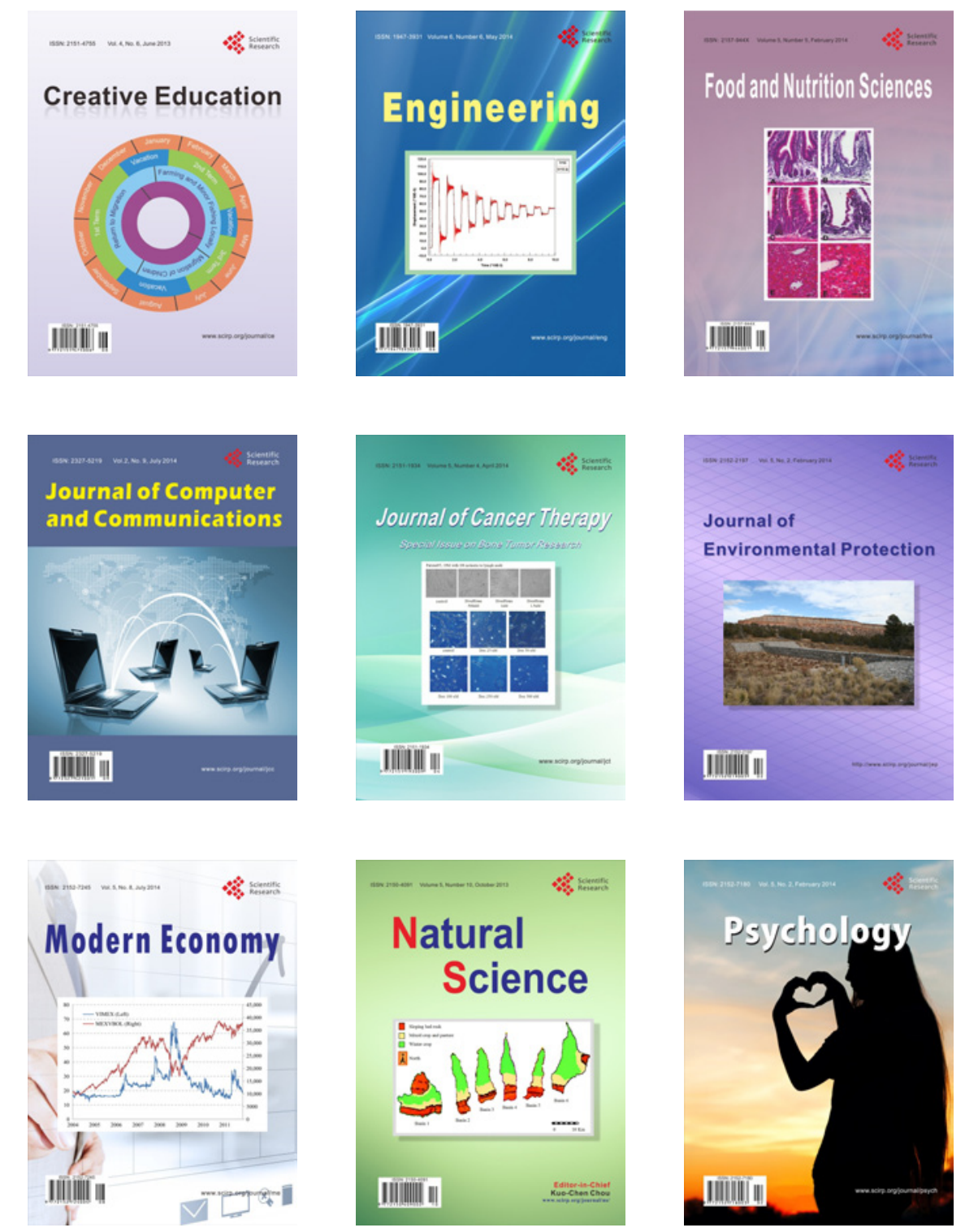